\title{
Blood Volume
}

National Cancer Institute

\section{Source}

National Cancer Institute. Blood Volume. NCI Thesaurus. Code C137837.

The total volume of blood in the circulatory system of an individual. 